\title{
Interpretasi Struktur Geologi Berdasarkan Fault Fracture Density (FFD) dan Implikasinya Terhadap Potensi Likuefaksi di Daerah Kalibening, Kabupaten Banjarnegara, Jawa Tengah
}

\author{
Interpretation of Geological Structures Based on Fault Fracture Density \\ (FFD) and Its Implications to Liquefaction Potential in \\ Kalibening Area, Banjarnegara Regency, Central Java
}

\author{
Huzaely Latief Sunan ${ }^{1 *}$, Akhmad Khahlil Gibran ${ }^{1}$, Maulana Rizki Aditama ${ }^{1}$, Sachrul Iswahyudi $^{1}$, \\ Fajar Rizki Widiatmoko ${ }^{2}$, Asmoro Widagdo', FX Anjar Tri Laksono ${ }^{1}$ \\ ${ }^{1}$ Jurusan Teknik Geologi, Fakultas Teknik, Universitas Jenderal Soedirman \\ Jl. Raya Mayjend Sungkono km 5, Kabupaten Purbalingga, Jawa Tengah, Indonesia, 53371 \\ ${ }^{2}$ Fakultas Teknologi Mineral dan Kelautan, Institut Teknologi Adhi Tama Surabaya (ITATS) \\ Jl. Arief Rachman Hakim 100, Kota Surabaya, Jawa Timur, Indonesia, 60117 \\ *E-mail: huzaely.sunan@unsoed.ac.id
}

Naskah diterima: 28 November 2020, direvisi: 21 April 2021, disetujui: 3 Mei 2021

DOI: 10.17146/eksplorium.2021.42.1.6129

\begin{abstract}
ABSTRAK
Keberadaan struktur geologi sering dikaitkan dengan bencana tanah longsor dan gempa bumi. Daerah Kalibening merupakan lokasi yang cukup menarik untuk dilakukan penelitian terkait hal tersebut. Daerah ini tersusun atas satuan batuan berumur Pleistosen dan Resen. Berdasarkan stratigrafinya, batuan tersebut terpotong oleh struktur sesar. Hal ini berarti menjadikan sesar di daerah tersebut termasuk dalam kategori sesar aktif. Morfologi yang tinggi dengan suatu cekungan di tengahnya mengindikasikan bahwa daerah tersebut pembentukannya dipengaruhi oleh sesar. Penelitian ini bertujuan untuk menentukan pola struktur geologi yang mengontrol daerah penelitian. Untuk menentukan pola struktur geologi, digunakan metode pemetaan struktur Fault Fracture Density (FFD) yang dikombinasikan dengan peta residual anomali Bouguer dan peta kelurusan hillshade. Secara umum, hal yang paling penting dalam mempelajari struktur geologi adalah geometri elemen struktur. Model konseptual struktur geologi selanjutnya digunakan untuk menganalisis potensi likuefaksi yang ada pada daerah penelitian. Interpretasi struktur menunjukkan adanya sesar mendatar dekstral yang diikuti sesar-sesar penyerta dan cekungan pull-apart yang diduga merupakan hasil pensesaran normal yang timbul dari mekanisme strike-slip. Sesar mendatar dekstral ini menghasilkan cekungan yang terisi oleh sedimen lepas yang rentan mengalami likuefaksi jika terjadi gempa bumi dan gerakan tanah. Kajian ini menyimpulkan bahwa daerah Kalibening rentan terjadi likuefaksi karena adanya pergerakan sesar mendatar dekstral, sedimen lepas yang mendominasi daerah penelitian, dan muka air tanah yang dangkal.
\end{abstract}

Kata kunci: Banjarnegara, Kalibening, struktur, likuefaksi

\begin{abstract}
The existence of geological structures is often associated with landslides and earthquakes. The Kalibening area is an interesting location for research on that purpose. This area is composed of Pleistocene and Recent rocks units. Based on its stratigraphy, the rocks in the area are truncated by fault structure. It means that the fault in the area is categorized as an active fault. The high morphology and a basin existence on its center indicate that the area formation was controlled by faults. The research is carried out to determine the trend of the geological structures that control the study area. To determine the trend of the geological structure, a structural mapping method of Fault Fracture Density (FFD) map combined with the Bouguer anomaly residual map and hillshade lineaments map is used. In general, the most important thing in the study of structural geology is the geometry of
\end{abstract}


the structural elements. The conceptual model of geological structures is subsequently used to analyze the liquefaction potential of the study area. The interpretation of the structures shows the existence of dextral strikeslip fault followed by companion faults and pull-apart basin that is inferred as the result of normal faulting in the strike-slip mechanism. The dextral strike-slip fault produces a basin filled with loose sediment that is prone to liquefaction in the event of an earthquake and ground motion. This study concludes that the Kalibening area is prone to liquefaction due to the existence of the movement of dextral strike-slip fault, loose sediments that dominate the study area, and shallow groundwater table.

Keywords: Banjarnegara, Kalibening, structure, liquefaction

\section{PENDAHULUAN}

Indonesia termasuk negara yang memiliki intensitas gempa bumi yang tinggi. Hal ini disebabkan karena lokasi Indonesia yang terletak pada pertemuan empat lempeng tektonik utama bumi, yaitu Eurasia, IndoAustralia, Pasifik, dan Filipina. Gempa bumi sering dikaitkan dengan fenomena likuefaksi. Likuefaksi adalah kondisi hilangnya kekuatan tanah sehingga tanah bersifat seperti fluida. Peristiwa likuefaksi dapat menimbulkan amblesan, keruntuhan, pengangkatan pada bangunan, retakan tanah, longsor, dan lainlain. Salah satu contoh dari pengaruh likuefaksi adalah kerusakan-kerusakan yang dihasilkan selama gempa bumi Bengkulu 2000, gempa bumi Aceh 2004, gempa bumi Nias 2005, dan gempa bumi Yogyakarta 2006 [1], [2]. Berdasarkan penelitian likuefaksi di beberapa negara, diketahui bahwa peristiwa likuefaksi bersifat ko-seismik dan sebaran kerusakan akibat likuefaksi pada umumnya hanya terjadi pada daerah yang terbentuk oleh lapisan sedimen granular yang jenuh air dengan kepadatan rendah, serta didukung oleh pergerakan ko-seismik di permukaan yang melebihi nilai ambang tertentu [3]. Beberapa faktor yang mesti diperhatikan dalam fenomena ini antara lain sifat keteknikan tanah, kondisi geologi, muka air tanah, dan karakteristik gempa bumi [3].

Zona sesar merupakan zona lemah yang mengakibatkan kekuatan batuan berkurang sehingga menimbulkan banyak rekahan/kekar yang memudahkan air meresap [4]. Daerah Kalibening merupakan daerah yang menarik untuk dilakukan penelitian tentang likuefaksi karena memiliki sesar aktif dan aluvium. Daerah ini memiliki beberapa litologi yang berbeda dengan kemiringan hampir datar sampai terjal serta dipengaruhi oleh struktur geologi yang beragam. Penelitian dilakukan untuk mengetahui pola struktur geologi dan potensi likuefaksi di daerah penelitian.

Menurut beberapa peneliti terdahulu, struktur perlapisan berupa kontak antara batulempung dan breksi berpotensi menyebabkan longsor [5]. Struktur geologi terbukti menyebabkan longsor di daerah Karangkobar tetapi belum ada penelitian lebih spesifik mengenai potensi likuefaksinya [6]. Oleh karena itu, penelitian ini difokuskan untuk mengetahui pola stuktur yang bekerja dan potensi terjadinya likuefaksi apabila terjadi gempa bumi atau longsor. Fault Fracture Density (FFD) adalah metode sederhana yang digunakan untuk menilai tingkat kepadatan struktur pada suatu lokasi yang yang memiliki struktur yang terinterkoneksi [7], [8].

\section{KONDISI GEOLOGI}

Secara regional, daerah penelitian terpetakan dalam Peta Geologi Lembar Banjarnegara skala 1:100.000 [9] (Gambar 1). Terlihat pada gambar bahwa daerah penelitian didominasi endapan danau dan aluvium. 


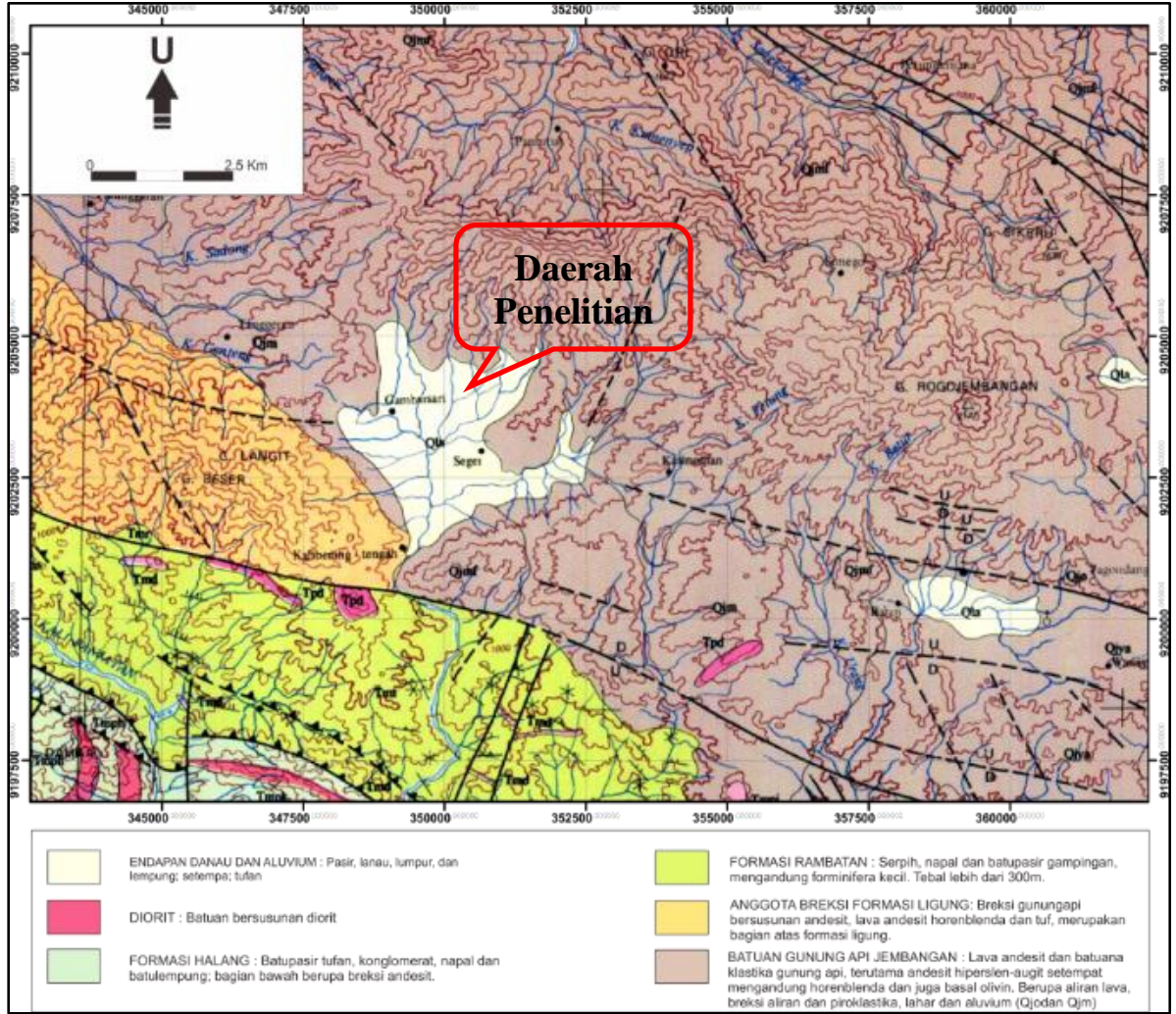

Gambar 1. Modifikasi peta geologi regional Banjarnegara-Pekalongan [9].

\section{Stratigrafi Regional}

Stratigrafi regional berdasarkan zona fisiografi Serayu Utara yang dirangkum oleh peneliti sebelumnya [9], [10] adalah sebagai berikut (Gambar 2).

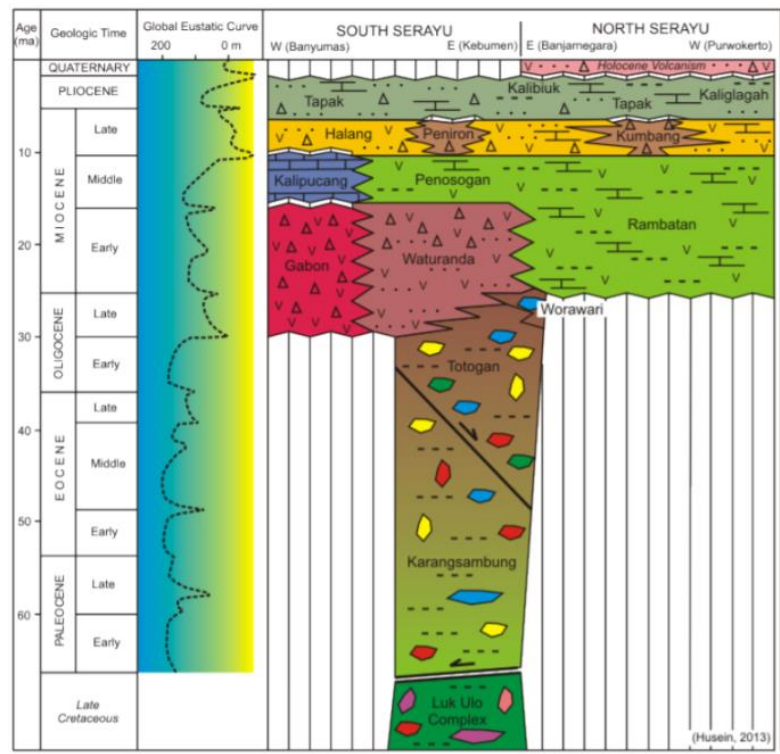

Gambar 2. Kolom stratigrafi regional daerah penelitian [10], [11].
Gunung Api Holosen meliputi produk gunung api pada Kala Holosen seperti Gunung Api Jembangan (Qj), Anggota Breksi Formasi Ligung (QTlb), dan Anggota Batulempung Formasi Ligung (QTlc). Batuan Gunung Api Holosen pada daerah penelitian tersusun atas breksi vulkanik dan lava andesit. Pada bagian atasnya terdapat aluvium. Aluvium ini terakumulasi pada daerah Kalibening karena terendapkan dalam sebuah cekungan yang dikontrol oleh graben.

\section{Struktur Geologi}

Pulau Jawa mempunyai tiga pola kelurusan dominan yang terbentuk akibat periode pembentukan struktur di Indonesia bagian barat [12] (Gambar 3), yaitu:

a. Pola Meratus yang berarah timur lautbarat daya (NE-SW) terbentuk pada 80 53 juta tahun yang lalu (Kapur AkhirEosen Awal). Pola ini diwakili oleh Sesar Cimandiri di Jawa Barat yang dapat 
dilacak ke arah timur laut sampai batas timur Cekungan Zaitun dan Cekungan Biliton.

b. Pola Sunda berarah utara-selatan (N-S) yang terbentuk pada 53-32 juta tahun yang lalu (Eosen Awal-Oligosen Awal). Pola Sunda diwakili oleh sesar-sesar yang membatasi Cekungan Asri, Cekungan Sunda, dan Cekungan Arjuna.

c. Pola Jawa berarah barat-timur (W-E) yang terbentuk pada 32 juta tahun yang lalu. Pola Jawa ini diwakili oleh sesarsesar naik seperti Sesar Baribis dan sesar lain yang berada di dalam Zona Bogor.

Merujuk pada pembagian periode rezim pergerakan tektonik [12], struktur geologi daerah penelitian terbentuk pada periode ketiga yang memiliki Pola Jawa berarah barat-timur (W-E). Hal ini didasarkan pada hasil interpretasi kelurusan dan pola sesar daerah penelitian yang berarah barat-timur (W-E).

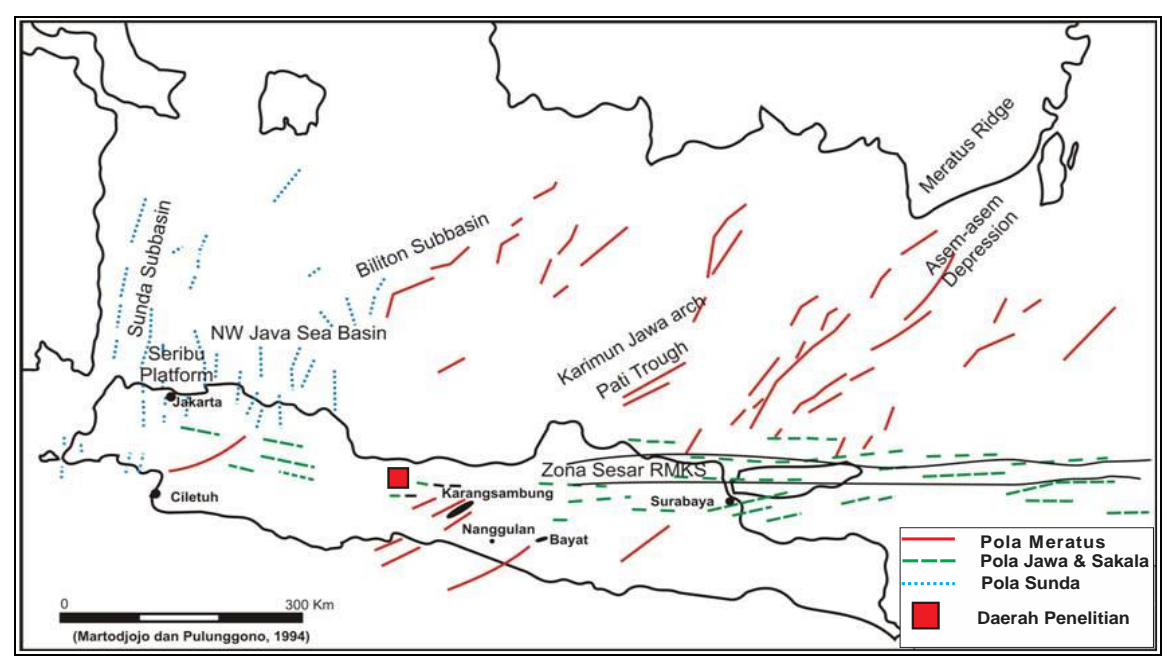

Gambar 3. Pola struktur Pulau Jawa [12].

\section{METODE PENELITIAN}

Metode yang digunakan dalam penelitian adalah analisis Digital Elevation Model Nasional (DEMNAS) Indonesia, analisis peta FFD, anomali gaya berat (Bouguer), dan analisis Normalized Difference Water Index (NDWI). Tiga metode pertama dilakukan untuk menginterpretasi pola struktur geologi di daerah penelitian. Data tersebut kemudian diproses untuk menentukan model konseptual struktur geologi daerah penelitian. Analisis NDWI berguna untuk melihat kejenuhan air pada aluvium sebelum dan sesudah terjadi gempa bumi [13], [14].

Data yang digunakan dalam analisis FFD adalah DEMNAS. Data tersebut diekstrak menjadi peta hillshade dengan menerapkan sudut penyinaran matahari sebesar $315^{\circ}$. Hasil analisis kelurusan adalah diagram roset dan parameter yang disebut sebagai FFD, yaitu pengukuran total panjang kelurusan per satuan luas (satuan: $\mathrm{km} / \mathrm{km}^{2}$ ). Untuk melakukan komputasi FFD, daerah penelitian dibagi dalam beberapa grid dengan ukuran 1x1 km. Hasil interpretasi kelurusan tersebut kemudian diukur nilainya dengan membagi total panjang kelurusan yang berada dalam grid dengan luas grid tersebut. Nilai tersebut diposisikan di tengah grid untuk selanjutnya dibuat peta kontur FFD.

Hasil analisis data gaya berat yang berasal dari sebaran beda anomali medan gravitasi data satelit menunjukkan adanya graben atau cekungan yang berada di antara 
tinggian. Indikasi graben ditunjukkan oleh nilai residual di lokasi tersebut yang lebih besar daripada di daerah sekitarnya. Pada data tersebut kemudian dilakukan pemisahan antara tren regional dengan tren lokal untuk mendapatkan anomali residual yang sensitif terhadap pola struktur geologi. Pola gaya berat tersebut dipetakan menggunakan "OASIS Montaj" dengan model single derivative untuk menggambarkan nilai densitas batuan di bawah permukaaan.

Pengolahan analisis NDWI dilakukan dengan menggunakan citra Landsat 8 OLI/TIRS yang telah dilakukan kalibrasi atmosferik dan koreksi radiometrik padanya. Hal ini bertujuan untuk mengubah data pada citra dari bentuk Digital Number (DN) menjadi radiance dan/atau reflectance. NDWI merupakan besaran indeks kebasahan pada permukaan tanah. Parameter yang digunakan adalah band Near Infrared (NIR) dan band Shortwave Infrared (SWIR). Persamaan yang digunakan adalah sebagai berikut :

$$
N D W I=\frac{N I R-S W I R}{N I R+S W I R}
$$

Setelah mendapatkan nilai NDWI kemudian dilakukan perbandingan antara kondisi pra-seismic dengan post-seismic untuk mengetahui perbedaan kejenuhan air pada daerah penelitian. Zona yang memiliki anomali gaya berat, jenuh air baik sebelum maupun sesudah gempa, serta didominasi oleh sedimen lepas dapat diklasifikasikan ke dalam zona rentan likuefaksi.

\section{HASIL DAN PEMBAHASAN}

Hasil analisis kelurusan menunjukkan pola berarah timur laut-barat daya ( $N W-S E)$ (Gambar 4). Hasil kelurusan yang dihubungkan dengan kondisi morfologi khas pada daerah struktural dan umur batuan yang tergolong masih muda (Kuarter) menjadikan lokasi penelitian menarik perhatian karena terdapat suatu depresi yang terisi oleh aluvium. Kenampakan depresi tersebut sangat mencolok dibandingkan dengan daerah sekitarnya. Melalui analisis kelurusan, peta FFD, dan anomali gaya berat diperoleh polapola sesar yang diduga aktif di daerah Kalibening. Semua metode analisis struktur menghasilkan interpretasi jenis sesar mendatar dekstral yang diduga mampu menghasilkan sebuah cekungan di antara tinggian. Cekungan ini terisi oleh sedimen lepas hasil erosi bukit-bukit yang mengelilinginya. Cekungan yang dihasilkan dari jenis sesar tersebut biasanya bersifat aktif. Perlu kajian lebih lanjut untuk membuktikan apakah cekungan tersebut aktif atau tidak. Potensi bencana yang perlu lebih diwaspadai di lokasi ini adalah likuefaksi.

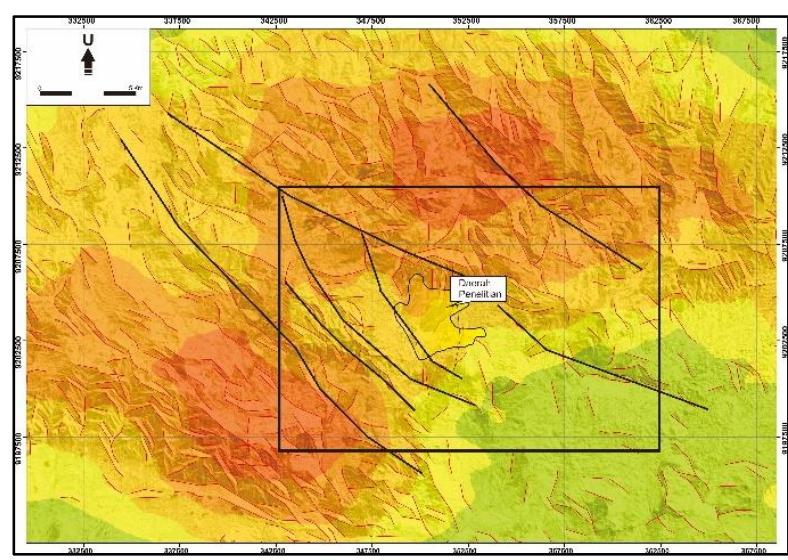

Gambar 4. Hasil ekstraksi citra Landsat full lineament menunjukkan pola kelurusan berarah $N W$-SE.

Nilai FFD rendah yang terdapat pada interpretasi depresi (Gambar 5) menunjukkan bahwa aktivitas struktur tidak terekam pada lokasi tersebut. Hal tersebut diduga disebabkan oleh kehadiran batuan lunak dan pengaruh kandungan air.

Pemodelan gaya berat menunjukkan kehadiran anomali gaya berat yang mengindikasikan adanya gejala struktur di 
daerah tersebut (Gambar 6 dan 7). Hasil analisis tersebut sesuai dengan hasil analisis NDWI pada saat sebelum dan sesudah gempa.

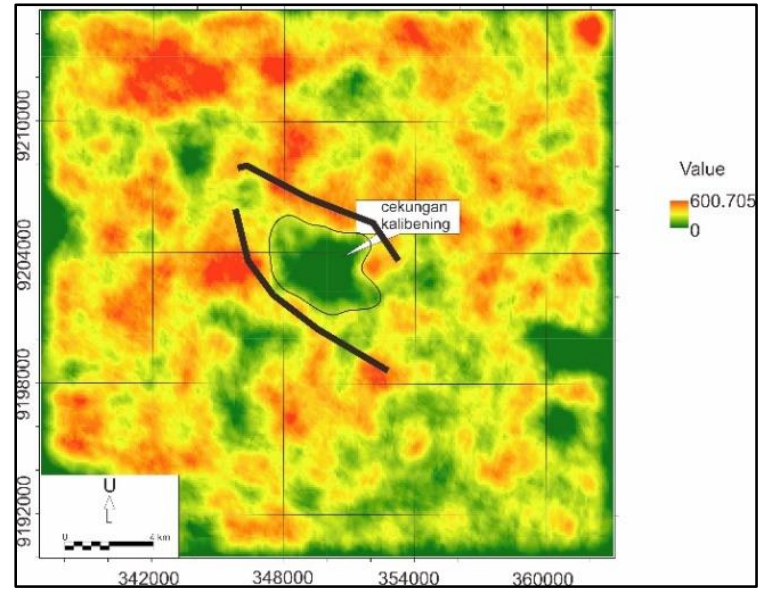

Gambar 5. Peta Fault Fracture Density (FFD).

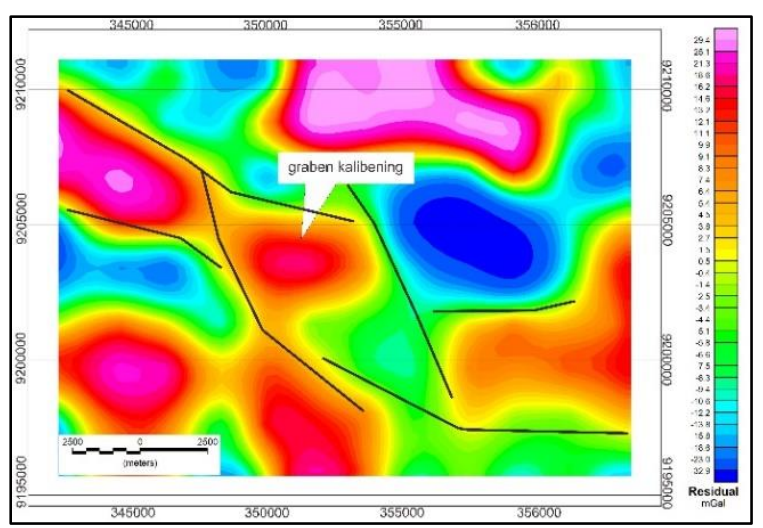

Gambar 6. Peta anomali gaya berat.

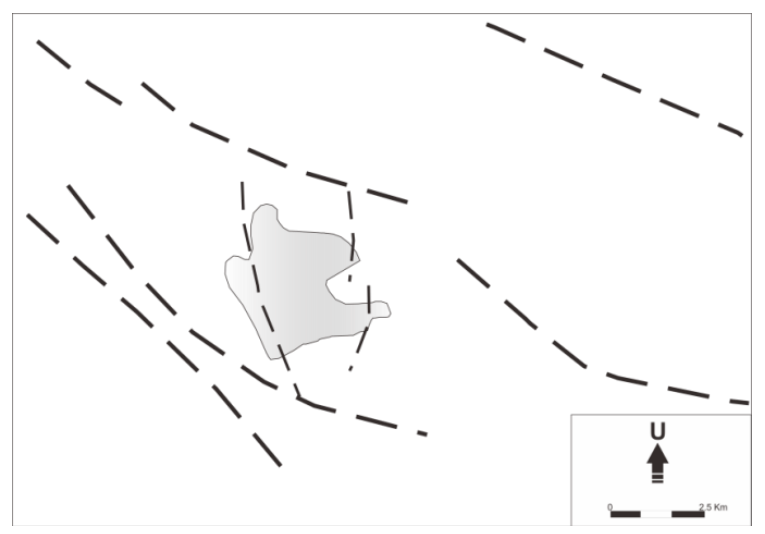

Gambar 7. Hasil interpretasi pola struktur geologi daerah penelitian.

Gambar 8 merupakan model konseptual sesar yang telah dibuat oleh peneliti terdahulu
[15]. Potensi likuefaksi di daerah penelitian merupakan implikasi dari proses sesar mendatar dekstral, termasuk pada zona releasing bend yang membentuk struktur graben. Graben ini kemudian terisi oleh sedimen lepas berukuran kerikil-lempung yang termasuk dalam material yang rawan mengalami likuefaksi.

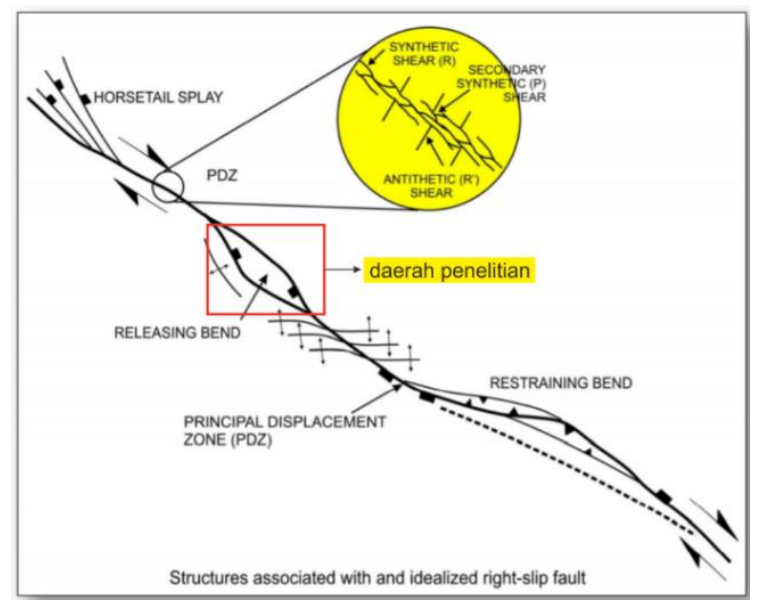

Gambar 8. Model konseptual sesar di daerah penelitian [15].

Hasil analisis NDWI memperlihatkan kejenuhan air sebelum terjadi gempa bumi (Gambar 9). Pada saat itu, kandungan air yang ada di permukaan relatif tinggi. Hasil analisis menunjukkan bahwa kejenuhan air setelah terjadi gempa semakin berkurang (Gambar 10). Hal ini menandakan terjadinya likuefaksi pada zona aluvium. Namun, likuefaksi yang terjadi tidak sebesar yang ada di Palu baru-baru ini. Indikasi likuefaksi menjadi salah satu perhatian lain selain adanya gempa bumi [16]. Gambar 10 juga sekaligus menunjukkan zona rentan likuefaksi bawah permukaan yang didominasi oleh sedimen lepas dan memiliki muka air tanah dangkal yang jenuh air. Ketika terjadi gempa, air ini mengurangi gaya tarik antarpartikel sedimen sehingga terjadilah fenomena likuefaksi. 


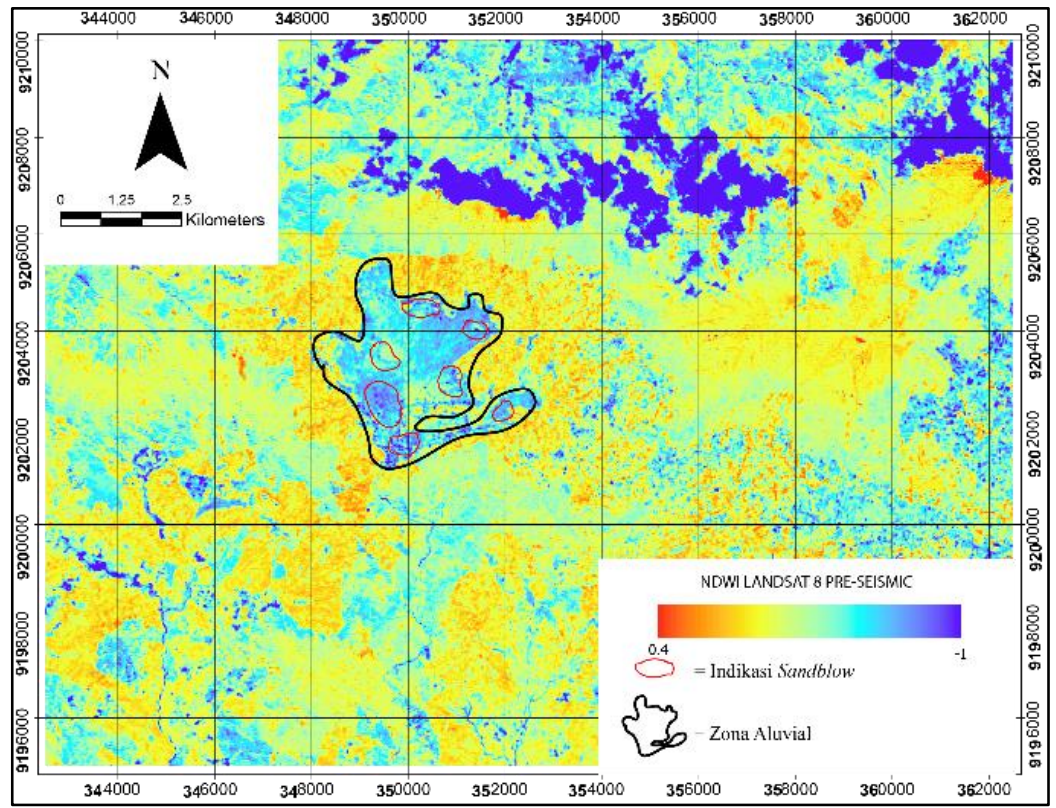

Gambar 9. Peta NDWI Kalibening sebelum terjadi gempa.

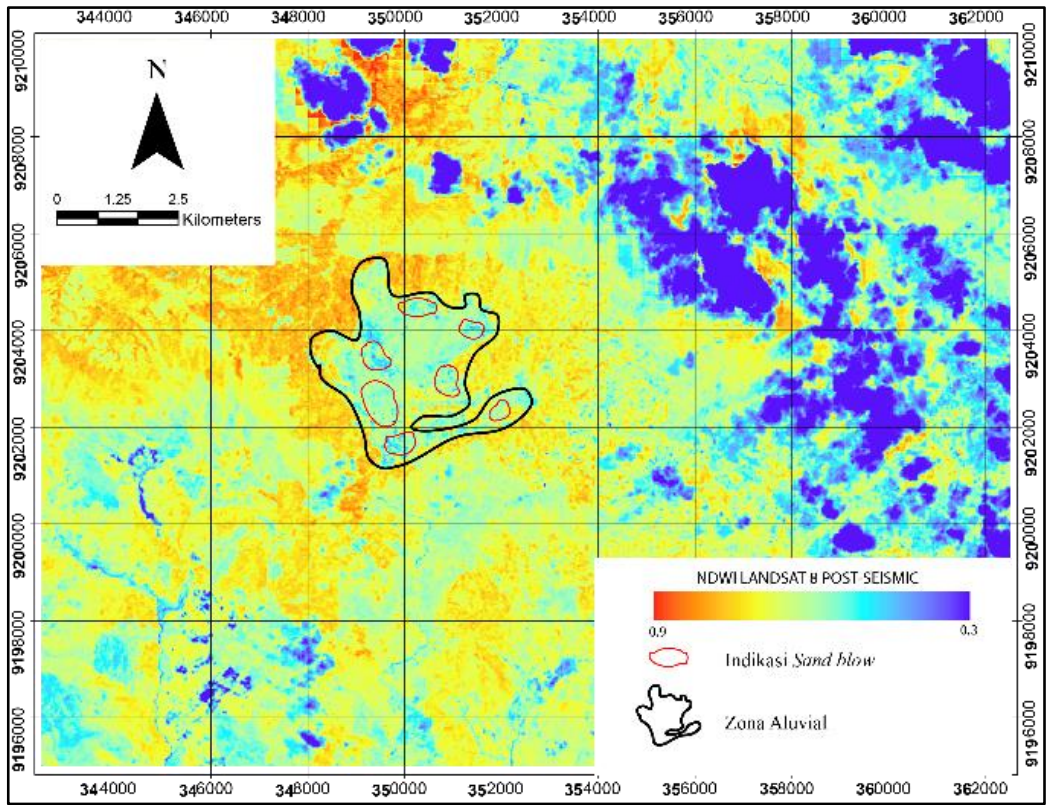

Gambar 10. Peta NDWI Kalibening sesudah terjadi gempa.

\section{KESIMPULAN}

Pola kelurusan struktur geologi daerah penelitian berarah barat laut-tenggara (NW$\mathrm{SE}$ ). Hasil interpretasi struktur sesar dari beberapa metode yang telah dilakukan menunjukkan bahwa jenis sesar yang bekerja pada daerah penelitian adalah sesar mendatar dekstral yang diikuti oleh sesar-sesar penyertanya serta dijumpainya cekungan pullapart yang diinterpretasikan sebagai hasil pensesaran normal yang terbentuk dalam mekanisme strike-slip. Cekungan tersebut terisi oleh sedimen lepas yang rentan terhadap likuefaksi jika terjadi gempa dan gerakan tanah. Daerah Kalibening termasuk dalam zona rentan likuefaksi yang disebabkan oleh adanya pergerakan sesar mendatar dekstral, sedimen lepas yang mendominasi daerah penelitian, dan muka air tanah yang dangkal. 


\section{UCAPAN TERIMA KASIH}

Kami menyampaikan terima kasih kepada rekan dosen dan mahasiswa Teknik Geologi yang telah ikut membantu dalam analisis data foto udara. Semoga tulisan ini berguna untuk penelitian berikutnya.

\section{DAFTAR PUSTAKA}

[1] F. A. Tri Laksono, M. R. Aditama, R. Setijadi, dan G. Ramadhan, "Run-up Height and Flow Depth Simulation of the 2006 South Java Tsunami Using COMCOT on Widarapayung Beach," 2020, doi: 10.1088/1757899X/982/1/012047.

[2] F. A. T. Laksono, G. Ramadhan, R. W. Nurmajid, L. A. G. Paramita, dan L. L.-Y. Tsai, "Analisis Zona Resapan dan Keluaran Air Tanah di Desa Kutayu, Kabupaten Brebes," Din. Rekayasa, vol. 16, no. 2, hal. 97-104, 2020, doi: 10.20884/1.dr.2020.16.2.321.

[3] H. B. Seed dan I. M. Idriss, "Simplified Procedure for Evaluating Soil Liquefaction Potential," ASCE J Soil Mech Found Div, vol. 97, no. $9,1971$.

[4] M. E. Fauzan, A. Damayanti, dan R. Saraswati, "Wilayah Potensi Bencana Tanah Longsor dengan Metode SINMAP di Daerah Aliran Ci Manuk Hulu, Kabupaten Garut, Jawa Barat," 2018.

[5] A. Widagdo, A. Candra, S. Iswahyudi, dan I. Abdullah, "Pengaruh Struktur Geologi Gunung Slamet Muda dan Tua Terhadap Pola Sebaran Panas Bumi," 2013.

[6] S. Iswahyudi, I. P. Jati, dan R. Setijadi, "Studi Pendahuluan Geologi Telaga Tirta Marta, Purbalingga, Jawa Tengah," Din. Rekayasa, vol. 14, no. 2, hal. 86-91, 2018.

[7] Oktoberiman, D. A. Ramadhan, F. R. Widiatmoko, dan R. T. Alya, "Identification of Geothermal Potential Based on Fault Fracture Density (FFD), Geological Mapping and Geochemical Analysis, Case Study: Bantarkawung, Brebes, Central Java," in KnE Energy, 2015, hal. 141-151, doi: 10.18502/ken.v2i2.369.

[8] Z. Agista, P. Rachwibowo, dan Y. Aribowo, "Analisis Litologi dan Struktur Geologi
Berdasarkan Citra Landsat pada Area Prospek Panasbumi Gunung Telomoyo dan Sekitarnya, Kabupaten Magelang, Provinsi Jawa Tengah," Geol. Eng. E-Journal, vol. 6, no. 1, hal. 278-293, 2014.

[9] W. H. Condon, L. Pardyanto, K. B. Ketner, T. C. Amin, dan S. Gafoer, "Peta Geologi Lembar Banjarnegara dan Pekalongan," Bandung, Indonesia, 1996.

[10] Aswan, Y. Zaim, Y. Rizal, dan U. Prasetyo, "Molluscan Evidence for Slow Subsidence in the Bobotsari Basin During the Plio-Pleistocene, and Implications for Petroleum Maturity," J. Math. Fundam. Sci., vol. 47, no. 2, hal. 185-204, 2015, doi: 10.5614/j.math.fund.sci.2015.47.2.6.

[11] A. N. Saerina, I. F. Romario, dan H. Nugroho, "Central Java Hydrocarbon Potential: North Serayu Petroleum System from Source to Trap Based on Geology, Geochemistry, and Geophysics Analysis,” 2016, doi: 10.2523/iptc18654-ms.

[12] A. Pulunggono dan S. Martodjojo, "Perubahan Tektonik Paleogen - Neogen Merupakan Peristiwa Terpenting di Jawa," in Proceedings Geologi dan geotektonik Pulau Jawa, 1994, hal. 253-274.

[13] S. K. McFeeters, "The Use of the Normalized Difference Water Index (NDWI) in the Delineation of Open Water Features," Int. J. Remote Sens., vol. 17, no. 7, hal. 1425-1432, 1996, doi: 10.1080/01431169608948714.

[14] B. C. Gao, "NDWI - A Normalized Difference Water Index for Remote Sensing of Vegetation Liquid Water From Space," Remote Sens. Environ., vol. 58, no. 3, hal. 257-266, 1996, doi: 10.1016/S0034-4257(96)00067-3.

[15] J. D. Moody dan M. J. Hill, "Moody and Hill System of Wrench Fault Tectonics: REPLY," Am. Assoc. Pet. Geol. Bull., vol. 48, no. 1, hal. 112-122, 1964, doi: 10.1306/bc743bd1-16be$11 \mathrm{~d} 7-8645000102 \mathrm{c} 1865 \mathrm{~d}$.

[16] T. Kurniawan, Y. H. Perdana, T. A. P. Setiadi, S. Rohadi, dan B. Sunardi, "Minimum Isoseismal Distribution Based On Macroseismic Interpolation For Earthquake Disaster Mitigation in Palu City," JGISE J. Geospatial Inf. Sci. Eng., vol. 2, no. 1, hal. 121-131, 2019, doi: $10.22146 /$ jgise .40763 . 